Огляди літератури, оригінальні дослідження, погляд на проблему, випадок з практики, короткі повідомлення УДК 612.015.3-02:616-056.2-06:612.015.6:577.161.2]-053.6

DOI 10.11603/1811-2471.2019.v0.i2.10367

\title{
FEATURES OF LIPID METABOLISM IN OVERWEIGHT AND OBESE ADOLESCENTS DEPENDING ON THE VARIOUS LEVELS OF VITAMIN D
}

\section{A-M. A. Shulhai, H. A. Pavlyshyn \\ I. Horbachevsky Ternopil National Medical University}

SUMMARY. Vitamin D deficiency and overweight have now become an important global problem in the field of health care as well as public health. A substantial hypovitaminosis D in children with obesity is often accompanied by metabolic disorders.

The aim of the study was to determine the relationship between the levels of vitamin D and lipid metabolism markers in adolescents with overweight and obesity.

Material and methods. 139 adolescents were examined (63 (45.4\%) girls and 76 (54.7 \%) boys). Depending on the body mass index (BMI) 65 children were overweight and 74 were obese children. The mean age of teenagers was $(15,4 \pm 2,3)$ years. To establish vitamin D status using the immune-enzyme method, blood serum levels of 25(OH)D were determined. Lipid metabolism markers were determined using the Roche Diagnostics Cholesterol reagent kit using and automatic Cobas c111 analyzer.

Results. The study established a direct relationship between the level of vitamin D and high-density lipoprotein cholesterol and indirect with total cholesterol, triglycerides, low-density lipoprotein cholesterol, atherogenic index, body mass index and waist circumference. Using a simple linear regression analysis, it was determined that total cholesterol, low-density lipoprotein cholesterol and atherogenic index have the greatest correlation with vitamin D.

Conclusions: Vitamin D deficiency in overweight and obese adolescents is associated with an increase in the body mass index, blood pressure, and atherogenic dyslipidemia.

KEY WORDS: vitamin D, obesity, calcidiol, cardiometabolic risk, adolescents.

Introduction. Vitamin D deficiency and overweight have now become an important global problem in the field of health care as well as public health. The prevalence of vitamin $D$ deficiency in patients who are overweight and obese varies from $5.6 \%$ to $96 \%$ in different countries [1].

In the last decade, studies have established a wide pleiotropic effect of vitamin $D$ on organs and tissues of the body. The relationship between vitamin $D$ deficiency and metabolic disorders in patients who are overweight and obese is particularly widespread [2].

There is increasing evidence of the effect of vitamin D deficiency in developing metabolic syndrome as well as lipid and carbohydrate metabolism disorders [3]. Researchers noted that vitamin D plays an important role in the regulation of glucose homeostasis, mechanisms of insulin secretion and adipocytes inflammation, which is associated with obesity. The effect of vitamin $D$ in adipocytes inflammation in obesity occurs through the active metabolite calcitriol, which inhibits pro-inflammatory cytokines $[2,3]$, reducing their inflammatory activity in adipocytes and inflammation generally.

Vitamin D deficiency and excessive fat accumulation create mutual negative effects that reduce the bioavailability of vitamin $D$ [4].

Vitamin D counteracts gluconeogenesis, increases the high-density lipoprotein cholesterol concentration, promotes changes in the profile of adipokines and increases the role of leptin, in adipose tissue [1].
Researchers associate vitamin $D$ with proatherogenic cardiometabolic risk factors. It has been reported that vitamin $D$ deficiency is an independent predictor of elevated triglycerides [5]. Other studies have shown that vitamin $D$ supplementation could increase high-density lipoproteins and decrease triglycerides.

Scientists and clinicians point to the existing significant independent relationship of the main lipids biochemical characteristics with the levels of vitamin $D$, in particular, it is noted that taking vitamin $D$ contribute to lowering the level of cholesterol in the blood $[6,7]$.

Studies from different countries have shown a wide prevalence of vitamin $D$ deficiency among adolescents, including those who are overweight, and its relationship with the development of metabolic syndrome. However, there is no sufficient information about the characteristics of lipid metabolism markers depending on the various levels of vitamin $D$ in adolescents who are overweight and obese.

The aim of the study was to determine the relationship between the levels of vitamin $D$ and lipid metabolism markers in adolescents with overweight and obesity.

Materials and methods. The research was conducted on the basis of the communal institution of the Ternopil Regional Council "Ternopil Regional Children Clinical Hospital". The patient safety rules and the ethical standards and procedures for research with human beings (2000) were observed 
Огляди літератури, оригінальні дослідження, погляд на проблему, випадок з практики, короткі повідомлення

in carrying out the work. The Commission on Bioethics of the I. Horbachevsky Ternopil National Medical University granted permission to carry out this study.

139 adolescents were examined (63 (45.4\%) girls and 76 (54.7 \%) boys). Depending on the body mass index (BMI) 65 children were overweight and 74 were obese children. The mean age of teenagers was $(15,4 \pm 2,3)$ years.

Evaluation of sexual development was carried out according to Tanner criteria (stages 2-5). In order to compare serum calcidiol levels in adolescents with overweight and obesity, and calcidiol levels in adolescents with normal body weight (BMI less than $85^{\text {th }}$ percentile for the given age and gender), a control group of 63 healthy children, that was comparable to gender and age with comparison groups, was presented.

The inclusion criteria for the study were the following: body mass index of more than $85^{\text {th }}$ percentiles for overweight children and over $97^{\text {th }}$ percentiles for obesity according to age-sex nomograms, written informed consent of parents and patients for the examination, autumn-winter period. The exclusion criteria were: obesity was due to endocrine diseases, taking antiepileptic drugs or glucocorticoids, hereditary and congenital disorders, diabetes mellitus, taking drugs that affect blood pressure, informed consent was not obtained.

To determine vitamin $D$ status using the immuneenzyme method, blood serum levels of $25(\mathrm{OH}) \mathrm{D}$ were determined. Thus, 25-OH Vitamin D ELISA kit (EUROIMMUN, Germany) was used, with an intra-assay CV of 3.2-4.9\% and an inter-assay CV of 4.0-7.8\%. The assessment of the results of $25(\mathrm{OH}) \mathrm{D}$ level was conducted according to the recommendations of the International Society of Endocrinologists [8]. In order to differentiate the relationship between vitamin $D$ level and parameters of carbohydrate metabolism and anthropometric measurements, adolescents with excessive body weight and obesity were divided into 4 groups, according to the quartile level of calcidiol in blood serum. Group of the quartile 1 included 37 adolescents with 25(OH)D level less than $10 \mathrm{ng} / \mathrm{ml}$, group 2 included 71 adolescents with 25(OH)D level from $10 \mathrm{ng} / \mathrm{ml}$ to $20 \mathrm{ng} / \mathrm{ml}$, quartile 3 included 22 adolescents with $25(\mathrm{OH}) \mathrm{D}$ level from $20 \mathrm{ng} / \mathrm{ml}$ to $30 \mathrm{ng} / \mathrm{ml}$, quartile 4 included 9 adolescents with 25(OH)D level more than $30 \mathrm{ng} / \mathrm{ml}$.

Anthropometric examinations: body weight (within the accuracy of $0.1 \mathrm{~kg}$ ), height (within the accuracy of $0.1 \mathrm{~cm}$ ) - were carried out with the use of generally accepted methods with the help of floor weight, height meter and flexible centimeter tape. Waist circumference (WC) and hip circumference (HC) were measured in all adolescents. WC was measured with a tape measure at the point midway between the iliac crest and the costal margin (lower rib). HC was measured at the level of the greatest protrusion of the buttocks. Next the waist-hip ratio (WHR) was calculated as WC divided by HC. BMI was calculated according to the formula (mass $(\mathrm{kg}) /$ height $\left.{ }^{2}\left(\mathrm{~m}^{2}\right)\right)$.

BMI was assessed by percentile curves for girls and boys separately. Excessive body weight was diagnosed in cases where BMI was higher than $85^{\text {th }}$ to $97^{\text {th }}$ percentile, and obesity when BMI exceeded $97^{\text {th }}$ percentile according to gender and age.

To determine the lipid metabolism serum concentrations of total cholesterol (TC), high-density lipoprotein cholesterol (HDL-C) and triglycerides (TG) were measured by enzymatic colorimetric method, using the Cholesterol reagent by Roche Diagnostics test systems (Switzerland) and Cobas c111 automatic analyzer. Low-density lipoprotein cholesterol (LDL-C) was calculated by by the Friedewald equation (LDL-C=TC (TG/2.2+HDL-C)) and the calculation of very lowdensity lipoprotein (VLDL-C) was done by VLDLC= triglyceride/2.2. The atherogenic index (Al) was calculated as follows: $\mathrm{Al}=(\mathrm{TC}-\mathrm{HDL}-\mathrm{C}) / \mathrm{HDL}-\mathrm{C}$.

The statistical processing of the results of the conducted studies was carried out using statistical package STATISTICA 10.0 and table editor Microsoft Excel 2003. The assessment of the normality of the distribution of features in the variation series was carried out according to the Kolmogorov-Smirnov criterion. The quantitative data was presented as median (Me) and interquartile range, or mean values (M), and $95 \%$ confidence interval (95\% Cl). A comparison of two independent samples with the correct distribution was performed using the Student's t-criterion, and in the case of an incorrect distribution of values using the nonparametric U-MannWhitney U-criterion. Correlation analysis was performed to estimate the relation between Spirmen correlation coefficient and multiple regression analysis.

The significance of the differences between the values considered reliable at $p<0,05$.

Results and Discussion. The median values of vitamin $D$ levels in adolescents with normal body weight was $17.6(12.03 ; 25.4) \mathrm{ng} / \mathrm{ml}$, in overweight $14.5(10.2 ; 20.6) \mathrm{ng} / \mathrm{ml}$ and in obese $127(9.3 ; 17.3) \mathrm{ng} / \mathrm{ml}$. To establish the relationship between vitamin $\mathrm{D}$ level and lipid metabolism markers, adolescents with overweight and obesity were divided into 4 groups, according to the quartile level of serum vitamin $D$ (Fig. 1). To quartile I included 37 (26.6 \%) teenagers with deep vitamin D deficiency, to II quartile - 71 $(51.1 \%)$ adolescents with vitamin D deficiency, to III quartile - 22 (15.9\%) teenagers with insufficiency vitamin D levels in IV quartiles, 9 (6.4\%) adolescents with sufficient vitamin D levels. 
Огляди літератури, оригінальні дослідження, погляд на проблему, випадок з практики, короткі повідомлення

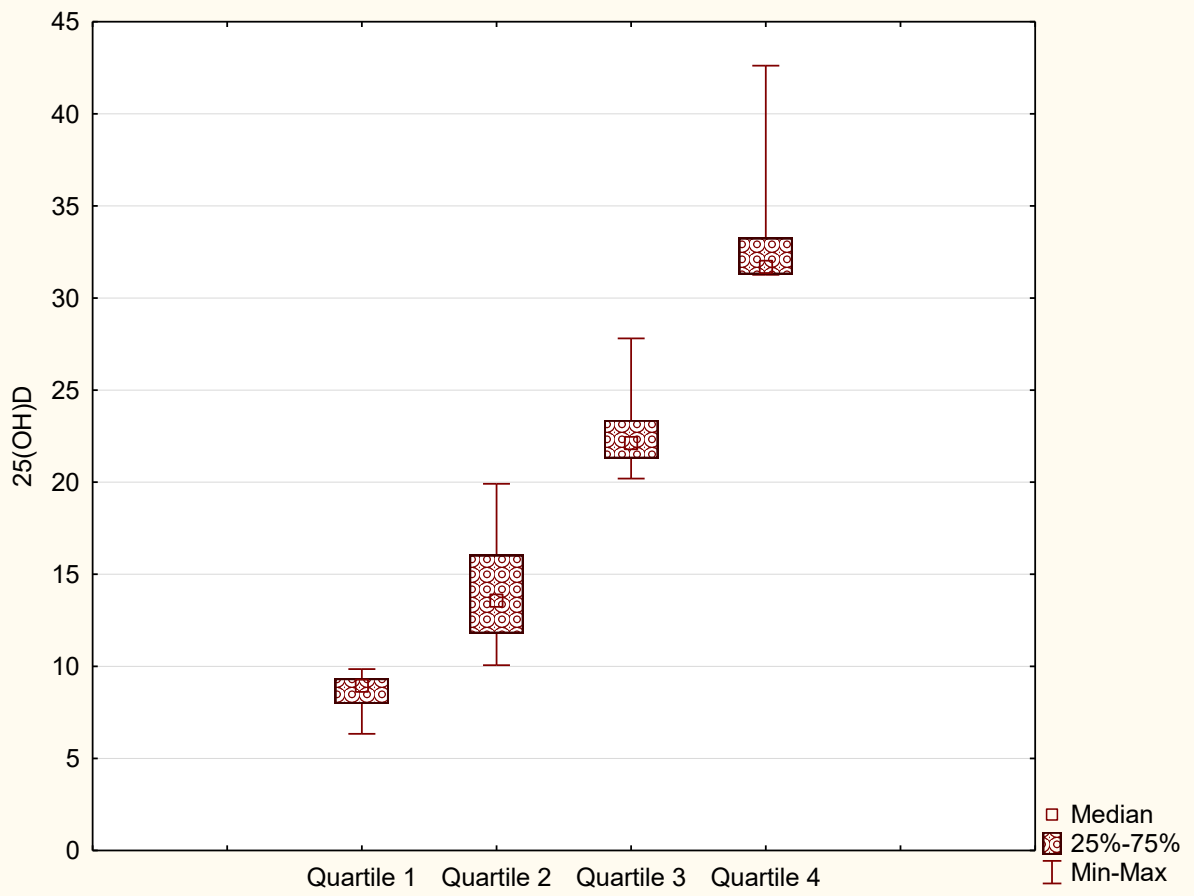

Fig. 1. Serum 25(OH)D content depending on the quartile distribution in overweight and obese adolescents.

The calcidiol level in quartile I was 8.58 (7.97; $9.34) \mathrm{ng} / \mathrm{ml}$, in quartile II $13.58(11.79 ; 16.05) \mathrm{ng} / \mathrm{ml}$, in quartile III $22.13(21.29 ; 23.37) \mathrm{ng} / \mathrm{ml}$ and in IV quartile $31.68(31.29 ; 33.26) \mathrm{ng} / \mathrm{ml}$.
Comparative data characteristics of anthropometric parameters, blood pressure and lipid metabolism markers depending on the quartile distribution of 25(OH)D level are presented in Table 1.

Table 1. Characteristics of anthropometric parameters, blood pressure and lipid metabolism markers in overweight and obese adolescents, depending on the quartile distribution of $25(\mathrm{OH}) \mathrm{D}, \mathrm{Me}(95 \% \mathrm{Cl})$

\begin{tabular}{|c|c|c|c|c|c|}
\hline Рагаmeters & $\begin{array}{l}\text { Quartile } 1 \\
\mathrm{n}=37\end{array}$ & $\begin{array}{c}\text { Quartile } 2 \\
\mathrm{n}=71\end{array}$ & $\begin{array}{c}\text { Quartile } 3 \\
n=22\end{array}$ & $\begin{array}{c}\text { Quartile } 4 \\
n=9\end{array}$ & $\begin{array}{c}\text { Certainty } \\
\text { coefficient, p }\end{array}$ \\
\hline 1 & 2 & 3 & 4 & 5 & 6 \\
\hline BMI, kg/m² & $\begin{array}{c}31.90 \\
(30.10-33.81)\end{array}$ & $\begin{array}{c}29.54 \\
(28.59-30.29)\end{array}$ & $\begin{array}{c}27.21 \\
(26.35-28.13)\end{array}$ & $\begin{array}{c}26.32 \\
(24.71-28.14)\end{array}$ & $\begin{array}{l}P_{1,2}=0.007 \\
P_{1,3}=0.000 \\
P_{1,4}=0.005\end{array}$ \\
\hline WC, cm & $\begin{array}{c}108.65 \\
(101.96-115.21)\end{array}$ & $\begin{array}{c}99.52 \\
(96.41-102.70)\end{array}$ & $\begin{array}{c}93.85 \\
(90.24-97.46)\end{array}$ & $\begin{array}{c}90.13 \\
(81.32-98.90)\end{array}$ & $\begin{array}{l}p_{1,2}=0.005 \\
p_{1,3}=0.001 \\
p_{1,4}=0.009\end{array}$ \\
\hline $\mathrm{SBP}, \mathrm{mm} \mathrm{Hg}$ & $\begin{array}{c}131.50 \\
(126.13-140.23)\end{array}$ & $\begin{array}{c}132.64 \\
(129.80-135.61)\end{array}$ & $\begin{array}{c}131.72 \\
(125.67-137.71)\end{array}$ & $\begin{array}{c}123.24 \\
(114.10-132.32)\end{array}$ & $\begin{array}{l}p_{1,2}=0.682 \\
p_{1,3}=0.968 \\
p_{1,4}=0.157\end{array}$ \\
\hline $\mathrm{DBP}, \mathrm{mm} \mathrm{Hg}$ & $\begin{array}{c}84.61 \\
(81.42-88.27)\end{array}$ & $\begin{array}{c}83.42 \\
(81.12-85.54)\end{array}$ & $\begin{array}{c}83.34 \\
(79.71-86.95)\end{array}$ & $\begin{array}{c}77.13 \\
(69.74-84.46)\end{array}$ & $\begin{array}{l}p_{1,2}=0.510 \\
p_{1,3}=0.622 \\
p_{1,4}=0.042\end{array}$ \\
\hline $\mathrm{TC}, \mathrm{mmol} / \mathrm{l}$ & $\begin{array}{c}4.55 \\
(4.16-4.95)\end{array}$ & $\begin{array}{c}4.39 \\
(4.21-4.58)\end{array}$ & $\begin{array}{c}4.06 \\
(3.75-4.37)\end{array}$ & $\begin{array}{c}3.99 \\
(3.68-4.29)\end{array}$ & $\begin{array}{l}p_{1,2}=0.401 \\
p_{1,3}=0.081 \\
p_{1,4}=0.161\end{array}$ \\
\hline TG, mmol/l & $\begin{array}{c}1.46 \\
(1.24-1.69)\end{array}$ & $\begin{array}{c}1.30 \\
(1.21-1.39)\end{array}$ & $\begin{array}{c}1.18 \\
(1.06-1.31)\end{array}$ & $\begin{array}{c}1.12 \\
(1.04-1.21)\end{array}$ & $\begin{array}{l}p_{1,2}=0.103 \\
p_{1,3}=0.072 \\
p_{1,4}=0.377\end{array}$ \\
\hline $\mathrm{HDL}-\mathrm{C}, \mathrm{mmol} / \mathrm{l}$ & $\begin{array}{c}1.07 \\
(0.97-1.17)\end{array}$ & $\begin{array}{c}1.17 \\
(1.11-1.24)\end{array}$ & $\begin{array}{c}1.27 \\
(1.18-1.37)\end{array}$ & $\begin{array}{c}1.29 \\
(1.014-1.44)\end{array}$ & $\begin{array}{l}p_{1,2}=0.072 \\
P_{1,3}=0.007 \\
P_{1,4}=0.040\end{array}$ \\
\hline
\end{tabular}


Огляди літератури, оригінальні дослідження, погляд на проблему, випадок з практики, короткі повідомлення

End of Table 1

\begin{tabular}{|c|c|c|c|c|c|}
\hline 1 & 2 & 3 & 4 & 5 & 6 \\
\hline LDL-C, mmol/l & 2.81 & 2.62 & 2.24 & 2.18 & $p_{1,2}=0.273$ \\
& $(2.46-3.15)$ & $(2.46-2.78)$ & $(1.94-2.53)$ & $(1.77-2.59)$ & $p_{1,3}=0.025$ \\
& & & & & $p_{1,4}=0.050$ \\
\hline VLDL-C, mmol/l & 0.67 & 0.59 & 0.54 & 0.51 & $p_{1,2}=0.103$ \\
& $(0.57-0.77)$ & $(0.55-0.63)$ & $(0.48-0.60)$ & $(0.47-0.55)$ & $p_{1,3}=0.071$ \\
& & & & & $p_{1,4}=0.377$ \\
\hline Al & 3.49 & 2.91 & 2.26 & 2.18 & $p_{1,2}=0.019$ \\
& $(3.01-3.98)$ & $(2.65-3.16)$ & $(1.91-2.62)$ & $(1.60-2.76)$ & $p_{1,3}=0.001$ \\
& & & & $p_{1,4}=0.012$ \\
\hline
\end{tabular}

Note. Data is presented as a median Me $(95 \% \mathrm{Cl})$. BMI - body mass index, WC - waist circumference, SBP - systolic blood pressure, DBP - diastolic arterial pressure, TC - total cholesterol, HDL-C - high-density lipoprotein cholesterol, LDL-C - low-density lipoprotein cholesterol, VLDL-C - very low-density lipoprotein, TG - triglycerides, Al - atherogenicity index, $\mathrm{P}_{12}$ - the certainty of the difference between the indicators of groups of quartile I and II, $\mathrm{P}_{1,3}$ - the certainty of the difference between the indicators of groups of quartile I and III, $\mathrm{p}_{1,4}$ - the certainty of the difference between the indicators of groups of quartile I and IV.

Studies have found that the average value of $25(\mathrm{OH}) \mathrm{D}$ in serum is directly dependent on body mass index and increased with a decreasing in BMI. There was determined a significant difference in the decrease in the BMI when the serum calcidiol levels increase. The researchers note that the relationship between $\mathrm{BMI}$ and vitamin $\mathrm{D}$ deficiency in overweight and obesity is due to the sequestration of vitamin $D$ in adipose tissue, obese adolescents have more a passive lifestyle, and also nutrition mistakes, as a result, food supply does not provide enough vitamin $D$ [1].

It has been established that as $25(\mathrm{OH}) \mathrm{D}$ levels increase, a significant decrease in the waist circumference regardless of gender in $2\left(p_{1,2}=0.005\right)$, $3\left(p_{1,3}=0.001\right)$ and $4\left(p_{1,4}=0.009\right)$ groups.

An increase in both systolic and diastolic blood pressure was typical to adolescents with overweight and obesity. In children from 1, 2 and 3 groups, the mean values of systolic blood pressure prevailed $130 \mathrm{~mm} \mathrm{Hg}$. Art., and in a group 4 in most cases, the values for systolic and diastolic blood pressure corresponds to the prehypertension state [9]. The significant difference was determined by the value of diastolic blood pressure between 1 and 4 groups ( $p=0.042$ ). Thus, after comparing blood pressure data from all 4 observation groups we conclude that arterial hypertension, as a risk factor for cardiovascular diseases, was associated with vitamin $D$ deficiency and insufficiency. Researchers also proved that vitamin $D$ deficiency is directly associated with the pathogenesis of hypertension, due to its intensifying effects on the activity of the renin-angiotensin system [7]. Some researchers said that vitamin $D$ has a link with smooth muscle cells and can influence on their functional activity through vitamin $\mathrm{D}$ receptors, which are on the membranes of smooth muscle myocytes [3].

After comparison lipid metabolism markers in all groups, it has been established that the average values of total cholesterol, triglycerides, low-density lipoproteins cholesterol, very low-density lipoproteins cholesterol and atherogenic index in groups with deep vitamin $D$ deficiency, vitamin $D$ deficiency and insufficiency vitamin D levels were significantly higher than in the group with sufficient vitamin D levels. That is, $25(\mathrm{OH}) \mathrm{D}$ levels increase is associated with atherogenic lipids decrease, which may indicate antiatherogenic properties in vitamin D. The scatterplot of total cholesterol depending on the $25(\mathrm{OH}) \mathrm{D}$ levels, confirms its frequency with a low level of serum vitamin $D$ (Fig. 2). These data suggest that vitamin $D$ deficiency can cause a negative effect on lipid markers and contribute to increase in cardiovascular risk among adolescents with low levels of vitamin $D$. The obtained results confirm that HDL-C, LDL-C, and Al are reliable prognosticindices confirming the dyslipidemia changes dynamics in adolescents with overweight and obesity. The HDL-C levels changes depending on the 25(OH)D levels are presented in Fig. 3. Currently, $\mathrm{HDL}-\mathrm{C}$ is considered a universal screening test to determine dyslipidemia.

Regression analysis of the relationship between 25(OH)D and BMI, WC, lipid metabolism markers showed that vitamin $D$ levels have a significant prognostic effect on them (Table 2). A direct relation 25(OH)D was determined with $\mathrm{HDL}-\mathrm{C}$, and indirect with $\mathrm{BMI}$, WC, TC, LDL-C, VLDL-C, TC, AI. It was established a reliable level between 25(OH)D concentration and BMI $(p=0.000), W C(p=0.000)$, total cholesterol $(p=0.034)$ LDL-C ( $p=0.021), \mathrm{Al}(p=0.009)$ in obese adolescents.

Of all the independent indices that have a significant effect on the calcidiol level, the highest values were found in atherogenic factors of the lipid spectrum. The largest ones were determined by the values that are non-standardized B-coefficients in LDL-C.

Standardized beta-coefficients of simple linear regression have been established and show the relative contribution of calculated predictors in the vitamin $\mathrm{D}$ deficiency formation in obese adolescents. 
Огляди літератури, оригінальні дослідження, погляд на проблему, випадок з практики, короткі повідомлення

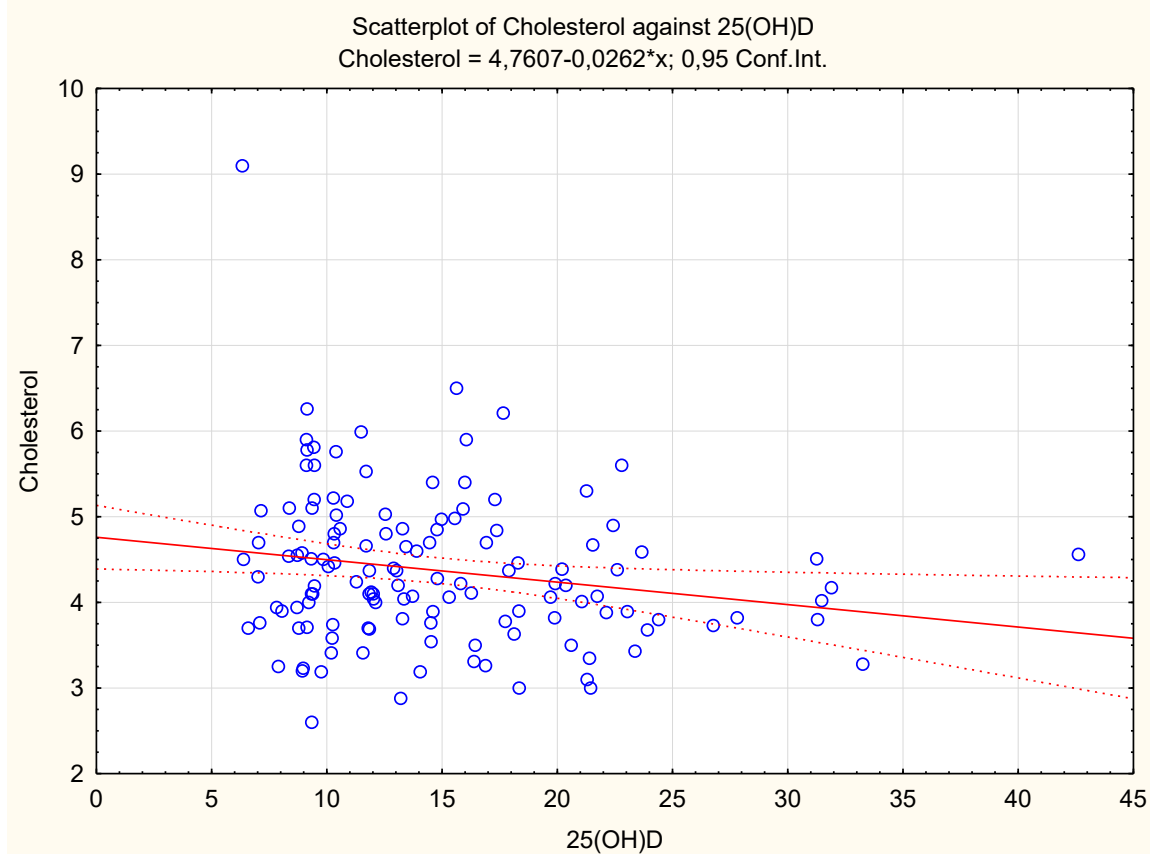

Fig. 2. The scatterplot of total cholesterol depending on the $25(\mathrm{OH}) \mathrm{D}$ levels in adolescents with overweight and obesity.

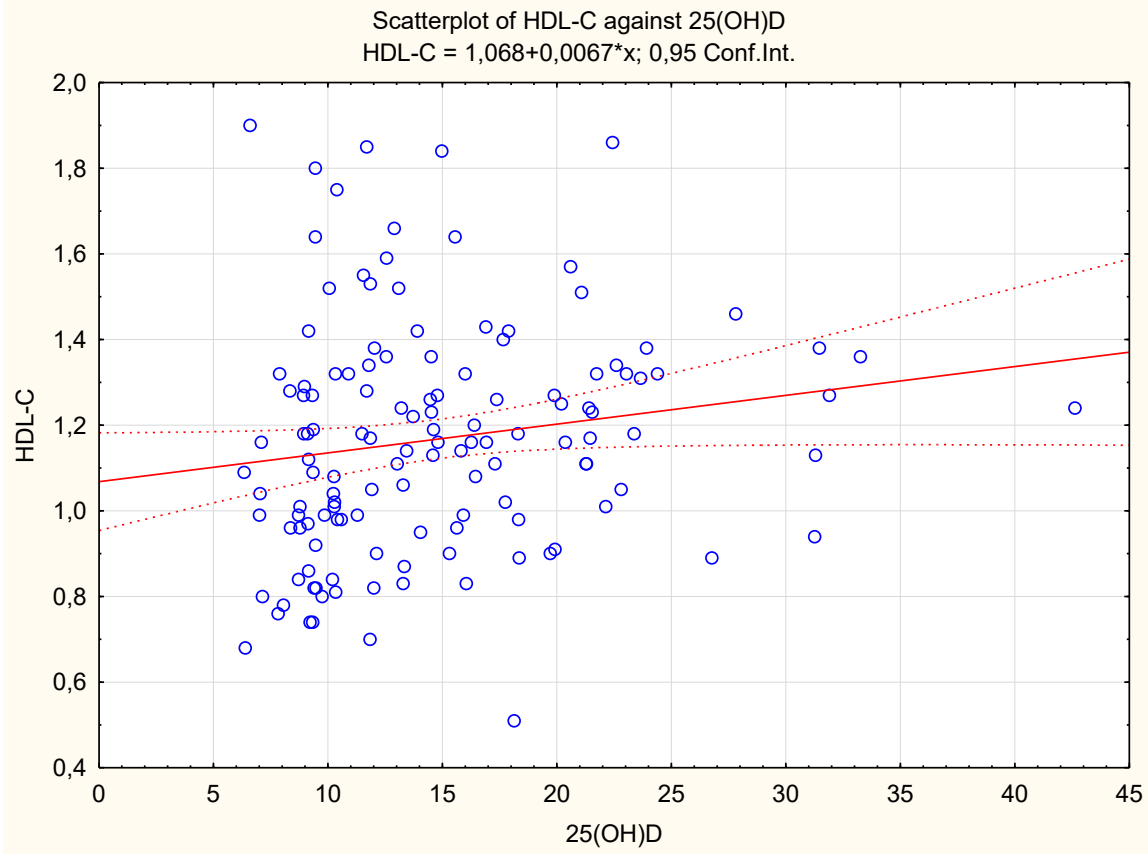

Fig. 3. The scatterplot of HDL-C levels depending on the 25(OH)D levels in adolescents with overweight and obesity.

Table 2. The simple linear regression analysis results of 25(OH)D and lipid metabolism markers and anthropometric measurements in obese adolescents

\begin{tabular}{|l|c|c|c|c|c|}
\hline \multicolumn{1}{|c|}{ Predictor } & B & Standart error, B & $\beta$ & Standart error, $\beta$ & $\begin{array}{c}\text { Certainty } \\
\text { coefficient, } P\end{array}$ \\
\hline \multicolumn{1}{|c|}{1} & 2 & 3 & 4 & 5 & 6 \\
\hline BMI & -0.944 & 0.138 & -0.623 & 0.091 & 0.000 \\
\hline Intercept & 44.492 & 4.518 & & & 0.000 \\
\hline WC & -0.173 & 0.039 & -0.461 & 0.103 & 0.000 \\
\hline
\end{tabular}


Огляди літератури, оригінальні дослідження, погляд на проблему, випадок з практики, короткі повідомлення

End of Table 2

\begin{tabular}{|l|c|c|c|c|c|}
\hline \multicolumn{1}{|c|}{1} & 2 & 3 & 4 & 5 & 6 \\
\hline Intercept & 32.773 & 4.288 & & & 0.000 \\
\hline TC & -1.427 & 0.663 & -0.244 & 0.114 & 0.034 \\
\hline Intercept & 20.328 & 3.061 & & & 0.000 \\
\hline HDL-C & 2.094 & 2.068 & 0.117 & 0.116 & 0.315 \\
\hline Intercept & 11.503 & 2.441 & & & 0.000 \\
\hline LDL-C & -1.814 & 0.767 & -0.266 & 0.113 & 0.021 \\
\hline Intercept & 18.874 & 2.201 & & & 0.000 \\
\hline VLDL-C & -4.426 & 2.519 & -0.201 & 0.114 & 0.083 \\
\hline Intercept & 16.665 & 1.706 & & & 0.000 \\
\hline TG & -2.031 & 1.155 & -0.201 & 0.115 & 0.083 \\
\hline Intercept & 16.665 & 1.706 & & & 0.000 \\
\hline Al & -1.311 & 0.492 & -0.297 & 0.112 & 0.009 \\
\hline Intercept & 18.110 & 1.703 & & & 0.000 \\
\hline
\end{tabular}

Note. B - non-standardized coefficient of regression. $\beta$-standardized regression coefficient

Conclusions. Vitamin D deficiency in overweight and obese adolescents is associated with an increase in the body mass index, blood pressure, and atherogenic lipid factors. Among the lipid metabolism markers, vitamin $D$ deficiency was related the

\section{LITERATURE}

1. Vitamin $D$ insufficiency in overweight and obese children and adolescents / I. Zakharova, L. Klimov, V. Kuryaninova [et al.] // Front. Endocrinol. (Lausanne). - 2019. Vol. 10. - P. 103-109.

2. Turer C. Prevalence of vitamin D deficiency among overweight and obese US children / C. Turer, H. Lin, G. Flores // Pediatrics. - 2013. - Vol. 131. - P.152-161.

3. Association between vitamin $D$ levels and cardiovascular risk factors in obese children and adolescents / A. Gul, S. Ozer, R. Yilmaz [et al.] // Nutr. Hosp. - 2017. Vol. 34. - P. 323-329.

4. Vitamin D status and cardiovascular risk in obesity: Effect of physical activity in nonvitamin $D$ supplemented adolescents / M. Hossain, A. Levinson, D. George [et al.] // Metab. Syndr. Relat. Disord. - 2018. - Vol. 16(4). - P. 197-203.

5. Vitamin D deficiency is an independent predictor of elevated triglycerides in Spanish school children / E. Rodriguez-Rodriguez, R. Ortega, L. Gonzalez-Rodríguez [et

\section{REFERENCES}

1. Zakharova, I., Klimov, L., Kuryaninova, V., Nikitina, I., Malyavskaya, S., Dolbnya, S., Kasyanova, A. et al. (2019). Vitamin D insufficiency in overweight and obese children and adolescents. Front. Endocrinol. (Lausanne), 10, 103-109.

2. Turer, C.B., Lin, H., \& Flores, G. (2013). Prevalence of vitamin $D$ deficiency among overweight and obese US children. Pediatrics, 131, 152-161.

3. Gul, A., Ozer, S., Yilmaz, R., Sonmezgoz, E., Kasap, T., Takçi, Ş., \& Demir, O. (2017). Association between vitamin $D$ levels and cardiovascular risk factors in obese children and adolescents. Nutr. Hosp., 34, 323-329.

4. Hossain, M.J., Levinson, A., George, D., Canas, J., Kumar, S., \& Balagopal, P.B. (2018). Vitamin D status and cardiovascular risk in obesity: Effect of physical activity in most with LDL-C, total cholesterol, and atherogenic index. It is necessary to introduce measures aimed at increasing the level of vitamin $\mathrm{D}$, reducing $\mathrm{BMI}$, atherogenic dyslipidemia and hypertension to prevent the development of cardiometabolic complications.

al.] // Eur. J. Nutr. - 2011. - Vol. 50 (5). - P. 373-378.

6. Vitamin $D$ deficiency associated with markers of cardiovascular disease in children with obesity / M. Censani, H. Hammad, P. Christos [et al.] // Glob. Pediatr. Health. 2018. - No. 5. - P. 23-37.

7. Associations between serum 25 -hydroxyvitamin $D$ and lipids, lipoprotein cholesterols, and homocysteine / C. Glueck, V. Jetty, M. Rothschild [et al.] // North Am. J. Med. Sci. - 2016. - No. 8. - P. 284-290.

8. Shulhai A.-M. Peculiarities of the prevalence and risk factors for vitamin d deficiency in overweight and obese adolescents in Ukraine / A.-M. Shulhai, H. Pavlyshyn, O. Shulhai // Archives of the Balkan Medical Union. - 2019. Vol. 54 (1). - P. 57-63.

9. Майданник В. Г. Артеріальна гіпертензія у дітей: діагностика та лікування / В. Г. Майданник, М.В.Хайтович // Внутренняя медицина. - 2008. - № 3 (9). С. 13-20.

nonvitamin D supplemented adolescents. Metab. Syndr. Relat. Disord., 16 (4),197-203.

5. Rodriguez-Rodriguez, E., Ortega, R.M., Gonzalez-Rodríguez, L.G., \& Lopez-Sobaler, A.M. (2011). Vitamin D deficiency is an independent predictor of elevated triglycerides in Spanish school children. Eur. J. Nutr., 50 (5), 373-378.

6. Censani, M., Hammad, H.T., Christos, P.J., \& Schumaker, T. (2018). Vitamin D deficiency associated with markers of cardiovascular disease in children with obesity. Glob. Pediatr. Health., 5, 23-37.

7. Glueck, C.J., Jetty, V., Rothschild, M., Duhon, G., Shah, P., Prince, M., Lee, K. et al. (2016). Associations between serum 25-hydroxyvitamin D and lipids, lipoprotein cholesterols, and homocysteine. North Am. J. Med. Sci., 8, 284-290. 
Огляди літератури, оригінальні дослідження, погляд на проблему, випадок з практики, короткі повідомлення

8. Shulhai, A.-M., Pavlyshyn, H., \& Shulhai, O. (2019). Peculiarities of the prevalence and risk factors for vitamin $D$ deficiency in overweight and obese adolescents in Ukraine. Archives of the Balkan Medical Union, 54 (1), 57-63.
9. Maydannyk, V.H., \& Khaitovych, M.V. (2008). Arterialna hipertenziia u ditei: diahnostyka ta likuvannia [Arterial hypertension in children: diagnostics and treatment]. Vnutrennyaya meditsyna - Internal Diseases, 3 (9), 13-20 [in Ukrainian].

\title{
ОСОБЛИВОСТІ ЛІПІДНОГО ОБМІНУ В ПІДЛІТКІВ ІЗ НАДМІРНОЮ МАСОЮ ТІЛА ТА ОЖИРІННЯМ ПРИ РІЗНИХ СТАНАХ ЗАБЕЗПЕЧЕННЯ ВІТАМІНОМ D
}

\author{
๑А-М. А. Шульгай, Г. А. Павлишин
}

Тернопільський національний медичний університет імені І. Я. Горбачевського МОз України

PEЗЮмЕ. Дефіцит вітаміну D та надмірна маса тіла на сьогодні стали важливою глобальною проблемою як охорони здоров'я, так і громадського здоров'я. Значне вираження гіповітамінозу D у дітей з ожирінням часто супроводжується метаболічними порушеннями.

Мета - визначити взаємозв'язки рівня вітаміну D з показниками ліпідного обміну у дітей підліткового віку з надмірною масою тіла та ожирінням.

Матеріал і методи. Обстежено 139 дітей підліткового віку, серед яких 65 було з надмірною масою тіла та 74 з ожирінням, в тому числі 63 (45,4 \%) дівчаток та 76 (54,7 \%) хлопчиків. Середній вік дітей склав $(15,4 \pm 2,3)$ року. Для встановлення вітамін D статусу за допомогою імуноферментного способу у сироватці крові рівень визначали 25(OH)D. Показники ліпідного обміну визначали з використанням набору Cholesterol reagent вiд Roche Diagnostics за допомогою автоматичного аналізатора Cobas c111.

Результати. Встановлено прямий взаємозв'язок рівня вітаміну D з холестерин ліпопротеїдами високої щільності та зворотний зв'язок із загальним холестерином, тригліцеридами, холестерин ліпопротеїдами низької щільності, індексом атерогенності та індексом маси тіла і окружністю талії. За допомогою простого лінійного регресійного аналізу визначено, що взаємозв'язок вітаміну D із показниками ліпідного обміну характеризувався найбільшими коефіцієнтами узагального холестерину, холестерин ліпопротеїдів низької щільності та індексу атерогенності.

Висновки. Дефіцит вітаміну D у підлітків з надмірною масою тіла та ожирінням асоціюється зі збільшенням індексу маси тіла, артеріального тиску та атерогенною дисліпідемією.

Ключові слова: вітамін D; ожиріння; кальцидіол; кардіометаболічний ризик; підлітки.

\section{ОСОБЕННОСТИ ЛИПИДНОГО ОБМЕНА У ПОДРОСТКОВ С ИЗБЫТОЧНОЙ МАССОЙ ТЕЛА И ОЖИРЕНИЕМ ПРИ РАЗНЫХ СОСТОЯНИЯХ ОБЕСПЕЧЕННОСТИ ВИТАМИНОМ D}

๑А-М. А. Шульгай, Г. А. Павлишин

Тернопольский национальный медицинский университет имени И. Я. Горбачевского МОз Украины

PЕЗЮМЕ. Дефицит витамина D и избыточная масса тела на сегодня стали важной глобальной проблемой как здравоохранения, так и общественного здоровья. Значительная выраженность гиповитаминоза $\mathrm{D}$ у детей с ожирением часто сопровождается метаболическими нарушениями.

Цель-определить взаимосвязи уровня витамина D споказателями липидного обмена удетей подросткового возраста с избыточной массой тела и ожирением.

Материал и методы. Обследовано 139 детей подросткового возраста, среди которых 65 было с избыточной массой тела и 74 с ожирением. Среди обследуемых было 63 (45,4 \%) девочки и 76 (54,7 \%) мальчиков. Средний возраст детей составил $(15,4 \pm 2,3)$ лет. Для установления витамин D статуса с помощью иммуноферментного метода определяли в сыворотке крови уровень 25 (ОН) D. Показатели липидного обмена определяли с использованием набора Cholesterol reagent от Roche Diagnostics с помощью автоматического анализатора Cobas c111.

Результаты. Установлена прямая взаимосвязь уровня витамина D c холестерин липопротеидами высокой плотности и обратная связь с общим холестерином, триглицеридами, холестерин липопротеидами низкой плотности, индексом атерогенности, а также с индексом массы тела и окружности талии. С помощью простого линейного регрессионного анализа определено, что наибольшей взаимосвязью с витамином D обладает общий холестерин, холестерин липопротеидов низкой плотности и показатель индекса атерогенности.

Выводы. Дефицит витамина D у подростков с избыточной массой тела и ожирением ассоциируется с увеличением индекса массы тела, артериального давления и атерогенной дислипидемии.

Ключевые слова: витамин D; ожирение; кальцидиол; кардиометаболический риск; подростки.

Отримано 25.04.2019 